\title{
Biofilm Formation and Antimicrobial Susceptibility of Non-Diphtheriae Corynebacterium Strains Isolated from Blood Cultures: First Report from Turkey
}

\author{
Kan Kültürlerinden Izole Edilen Difteri-Dışı Corynebacterium \\ Suşlarının Biyofilm Oluşturması ve Antimikrobiyal Duyarlılıkları: \\ Türkiye'deki ilk Bildirim
}

\section{Sinem OZDEMIR $\odot$, Okan AYDOGAN $\odot$, Fatma KOKSAL CAKIRLAR $\odot$}

Ethics Committee Approval: This study does not require an ethics commitee approval. Conflict of interest: The authors declare that they have no conflict of interest.

Funding: None.

Informed Consent: Informed consents were obtained from the patients who participated in the study with their clinical specimens.
Cite as: Ozdemir S, Aydogan O, Koksal Cakırlar F. Biofilm formation and antimicrobial susceptibility of non-diphtheriae Corynebacterium strains isolated from blood cultures: First report from Turkey. Medeni Med J. 2021;36:123-9.

\begin{abstract}
Objective: Non-diphtheriae Corynebacterium strains have been recognized as important pathogens after decades of confusion regarding their microbiological classification and clinical significance. The aim of this study was to identify non-diphtheriae Corynebacterium strains and the prevalence of biofilm formation and antimicrobial resistance.

Method: In total, 126 non-diphtheriae Corynebacterium strains were isolated from blood cultures of inpatients with bacteremia in our hospital between January 2015 and January 2020 . Blood cultures were analyzed with the Bactec-9120 system. Strains were identified using MALDI-TOF MS (Bruker Daltonics, Germany). Antimicrobial susceptibilities were determined using the Kirby-Bauer disk diffusion method on a MuellerHinton agar and evaluated according to EUCAST standards. Biofilm formation was assessed with the Congo Red Agar method.

Results: Corynebacterium striatum and Corynebacterium matruchotii were the most prevalent with 29 and 26 isolates, respectively. Biofilm production was detected in $62.06 \%(18 / 29)$ of C. striatum, in $53.8 \%(14 / 26)$ of C. matruchotii, in $50 \%$ (9/18) of Corynebacterium afermentans, $50 \%$ (6/12) of Corynebacterium amycolatum, and in 46\% (7/15) of Corynebacterium jeikeium strains. Among the five most prevalent strains, we found a high biofilm rate of $54 \%$. The resistance rates to penicillin, clindamycin, ciprofloxacin, rifampicin, tetracycline, and gentamicin were $91.2 \%, 87.3 \%, 79.3 \%, 56.3 \%, 45.2 \%$, and $39.6 \%$, respectively. All 126 strains were susceptible to vancomycin and linezolid.

Conclusion: Non-diphtheriae Corynebacterium strains isolated from blood cultures of hospitalized patients with bacteremia may have multidrug resistance and the ability to produce biofilm. These results emphasize the importance of identifying strains and determining their antimicrobial susceptibility and biofilm production potential.
\end{abstract}

Keywords: Corynebacterium striatum, Corynebacterium matruchotii, Corynebacterium afermentans, Corynebacterium amycolatum, Corynebacterium mucifaciens, Corynebacterium kutscheri

öz

Amaç: Difteri-dışı Corynebacterium suşları, mikrobiyolojik sınıflandırmaları ve klinik önemi ile onlarca yıllık kafa karısıklığının ardından önemli patojenler olarak kabul edilmistir. Bu calısmanın amacı, difteri-dısıı Corynebacterium suşlarının tür tayinin yapılması, biyofilm oluşumu ve antimikrobiyal direnç prevalansını araştırmaktır.

Yöntem: Ocak 2015-Ocak 2020 tarihleri arasında hastanemizde yatarak tedavi gören bakteriyemili hastaların kan kültürlerinden difteri olmayan 126 Corynebacterium suşu izole edildi. Kan kültürleri Bactec-9120 sistem ile analiz edildi. Suşların tanımlanması MALDI-TOF MS (Bruker Daltonics, Almanya) kullanılarak yapıldı. Antimikrobiyal duyarllıklar Mueller-Hinton agarda Kirby-Bauer disk difüzyon yöntemiyle belirlendi ve EUCAST standartlarına göre değerlendirildi. Biyofilm oluşumu Congo Red Agar yöntemi ile değerlendirildi.

Bulgular: Difteri-dısıı Corynebacterium suşları arasında Corynebacterium striatum ve Corynebacterium matruchotii sırasılyla 29 ve 26 izolatla en yaygın suşlard. Biyofilm üretimi C. striatum suşlarında \%62,06 (18/29), C. matruchotii suslarında \%53,8 (14/26), Corynebacterium afermentans suslarında $\% 50(9 / 18)$, Corynebacterium amycolatum suslarında $\% 50$ (6/12) ve Corynebacterium jeikeium suslarında \%46 (7/15) olarak tespit edilmistir. Çalışmanın en sık izole edilen ilk beş suşunda, \%54 gibi yüksek bir biyofilm oranı bulduk. Penisilin, klindamisin, siprofloksasin, rifampisin, tetrasiklin ve gentamisine direnç oranları sırasılyla \%91,2, \%87,3, \%79,3, \%56,3, $\% 45,2$ ve $\% 39,6$ olarak tespit edildi. 126 suşun tamamı vankomisin ve linezolide duyarlydil.

Sonuc: Bu sonuclar, hastanede yatan bakteriyemili hastaların kan kültürlerinden izole edilen Corynebacterium suşlarının biyofilm olușturma yeteneğiyle birlikte çoklu-ilaç direnci gösterdiklerini ve kontaminasyon olarak göz ardı edilmemesi için, tür tayini ve antibiyotik duyarlıı̆̆ının belirlenmesinin önemini vurgulamaktadır.

Anahtar kelimeler: Corynebacterium striatum, Corynebacterium matruchotii, Corynebacterium afermentans, Corynebacterium amycolatum, Corynebacterium mucifaciens, Corynebacterium kutscheri

(c) Copyright Istanbul Medeniyet University Faculty of Medicine. This journal is published by Logos Medical Publishing. Licenced by Creative Commons Attribution-NonCommercial 4.0 International (CC BY-NC 4.0)
Received: 8 March 2021

Accepted: 8 May 2021

Online First: 18 June 2021

Corresponding Author: O. Aydogan

ORCID: 0000-0001-7275-8724

Istanbul Medipol University School of Medicine, Department of Medical Microbiology, Istanbul, Turkey

okanaydogan@medipol.edu.tr

\section{S. Ozdemir}

ORCID: 0000-0002-2339-8571

F. Koksal Cakirlar

ORCID: 0000-0003-4279-434X

İstanbul University-Cerrahpaşa,

Cerrahpaşa School of Medicine, Department of Medical Microbiology, Istanbul, Turkey 


\section{INTRODUCTION}

Corynebacterium is a genus of aerobic, Grampositive, non-motile bacteria called "diphtheroids" or "coryneform". Corynebacterium spp. are typically club-shaped and nonsporulating rods. Corynebacterium spp. are divided into two groups: Corynebacterium diphtheriae and non-diphtheriae Corynebacterium $^{1,2}$.

Previously, C. diphtheriae was considered an agent that caused serious infections, whereas other non-diphtheriae Corynebacterium strains were dismissed as contaminating bacteria when isolated from clinical specimens. Recently, nondiphtheriae Corynebacterium spp. have been recognized as important pathogens after decades of confusion regarding their microbiological classification and clinical significance. Nondiphtheriae Corynebacterium spp. are normal flora bacteria in human skin and mucous membranes. When isolated from clinical specimens they cause serious infections and nosocomial outbreaks in critically ill immunocompromised patients, for example in those with end-stage cancer, hematologic malignancy, or who have prosthetic devices or stayed for prolonged periods in a hospital or nursing homes ${ }^{3-5}$. Nosocomial outbreaks, especially due to Corynebacterium striatum, are increasing in both industrialized and developing countries. C. striatum is associated with pulmonary infections, sepsis, endocarditis, meningitis, osteomyelitis, arthritis, sinusitis, skin wounds, and intrauterine infection ${ }^{6}$.

The ability to form biofilm plays a pivotal role in the pathogenesis of nosocomial infections, whether or not they are associated with devices. Biofilm makes it easier for opportunistic pathogens to adhere to catheters, implanted medical devices, and build multidrug resistance. Biofilm-associated infections are increasingly reported due to the growing elderly population and the use of implantable medical devices ${ }^{6-8}$. The aim of this study was to identify non-diphtheriae
Corynebacterium strains and the prevalence of biofilm formation and antimicrobial resistance.

\section{MATERIAL and METHOD}

The study was conducted according to the principles of the World Medical Association Declaration of Helsinki "Ethical Principles for Medical Research Involving Human Subjects" (amended in October 2013). Informed consent was obtained from the patients who participated in the study with their clinical specimens.

Intotal, 126non-diphtheriae Corynebacteriumstrains were isolated from patients' blood cultures between January 2015 and January 2020. The strains were isolated from routine clinical samples of inpatients with bacteremia in intensive care units and in other departments of İstanbul University-Cerrahpaşa, Cerrahpaşa School of Medicine Hospital. Only patients with at least two positive blood cultures were included. Corynebacterium diphtheriae and contaminated strains were excluded.

Blood cultures of 8-10 mL samples obtained from each patient were inoculated into BD BACTEC vials and incubated in the Bactec 9120 (Becton Dickinson, $M D, U S A)$ automated blood culture system. When Gram-positive pleomorphic bacilli were seen, colonies were identified using the matrix-assisted laser desorption/ionization time-of-flight method with MALDI-TOF MS (Bruker Daltonics, Germany). Antimicrobial susceptibilities were determined by the Kirby-Bauer disk diffusion method on MuellerHinton agar and evaluated according to the criteria of EUCAST (The European Committee on Antimicrobial Susceptibility Testing) ${ }^{9}$.

To qualitatively assess biofilm formation, we used the Congo Red Agar method following Ramos et al. ${ }^{10}$ (2019). Black colonies were considered strong biofilm producers and red colonies as nonbiofilm producers. 
S. Ozdemir et al. Biofilm Formation and Antimicrobial Susceptibility of Non-Diphtheriae Corynebacterium Strains Isolated from Blood Cultures: First Report from Turkey

\section{RESULTS}

Eighty-two (65\%) patients were from internal medicine wards, and 44 (35\%) were from intensive care units (ICUs; Table 1).

Among non-diphtheriae Corynebacterium strains, Corynebacterium striatum was the most prevalent isolate (n:29; 23.01\%), followed by C. matruchotii (n:26; 20.63\%), C. afermentans (n:18; 14.28\%), C. jeikeium (n:15; 11.9\%), C. amycolatum (n:12; 9.52\%), C. mucifaciens (n:6; 4.76\%), C. kutscheri (n:5; 3.96\%), C. pseudodiphtheriticum (n:3; 2.38\%, C. xerosis (n:3; 2.38\%), C. imitans 1 (n:2; 59\%), C. minutissimum (n:2; 1.59\%), and C. singulare, C. aguaticum, C. aurimucosum, C. propinquum, C. bovis (for each n: $1 ; 0.8 \%$ ).

Biofilm formation by non-diphtheriae Corynebacterium strains were determined as $50.8 \%$. Biofilm production was detected in $62.06 \%$ (18/29) of C. striatum, in $53.8 \%(14 / 26)$ of $C$. matruchotii, in $50 \%(9 / 18)$ of $C$. afermentans, in $50 \%(6 / 12)$ of $C$. amycolatum, and in $46 \%(7 / 15)$

Table 1. The distribution of the 126 non-diphtheriae Corynebacterium strains by hospital wards.

\section{Total (\%)}

\begin{tabular}{|c|c|c|c|c|c|c|}
\hline Internal Medicine & 7 & 8 & 19 & 21 & 17 & $72(57.1)$ \\
\hline $\begin{array}{l}\text { Pediatric Internal } \\
\text { Medicine }\end{array}$ & 1 & 1 & 5 & 2 & 1 & $10(8)$ \\
\hline Intensive Care Units & 6 & 5 & 15 & 6 & 6 & $38(30.1)$ \\
\hline $\begin{array}{l}\text { Pediatric Intensive } \\
\text { Care Units }\end{array}$ & - & 2 & 3 & 1 & - & $6(4.8)$ \\
\hline Total & 14 & 16 & 42 & 30 & 24 & $126(100)$ \\
\hline
\end{tabular}

of C. jeikeium strains (Table 2). C. singulare, C. aguaticum, C. aurimucosum, C. propinquum, and $C$. bovis were identified as non-biofilm producing isolates. Biofilm production rates of the

Table 2. Distribution of biofilm-forming non-diphtheria Corynebacterium spp.

\begin{tabular}{llr}
\hline Bofilm production & N & $\%$ \\
\hline C. striatum & $18 / 29$ & 62.0 \\
C. matruchotii & $14 / 26$ & 53.8 \\
C. afermentans & $9 / 18$ & 50.0 \\
C. jeikeium & $7 / 15$ & 46.0 \\
C. amycolatum & $6 / 12$ & 50.0 \\
C. mucifaciens & $3 / 6$ & 50.0 \\
C. kutscheri & $3 / 5$ & 60.0 \\
C. pseudodiphtheriticum & $1 / 3$ & 33.3 \\
C. xerosis & $1 / 3$ & 33.3 \\
C. imitans & $1 / 2$ & 50.0 \\
C. minutissimum & $1 / 2$ & 50.0 \\
C. singulare & $0 / 1$ & - \\
C. aguaticum & $0 / 1$ & - \\
C. aurimucosum & $0 / 1$ & - \\
C. propinquum & $0 / 1$ & - \\
C. bovis & $0 / 1$ & - \\
Total & $64 / 126$ & 50.8
\end{tabular}

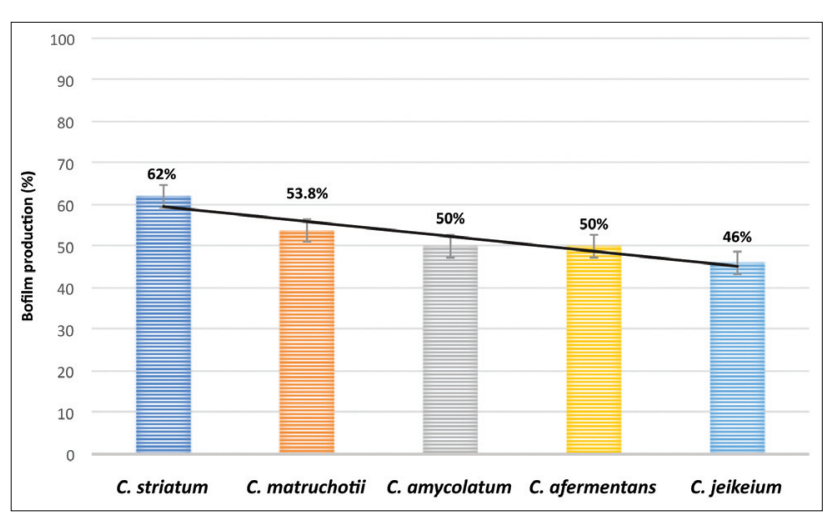

Figure 1. Biofilm production rates of top-five prevalent strains in the study.

Table 3. Distribution of antimicrobial resistance among non-diphtheriae Corynebacterium strains by years.

\begin{tabular}{|c|c|c|c|c|c|c|c|c|c|c|c|c|}
\hline & \multicolumn{2}{|c|}{2015} & \multicolumn{2}{|c|}{2016} & \multicolumn{2}{|c|}{2017} & \multicolumn{2}{|c|}{2018} & \multicolumn{2}{|c|}{2019} & \multicolumn{2}{|l|}{ Total } \\
\hline & $\mathbf{N}$ & $\%$ & $\mathbf{N}$ & $\%$ & $\mathbf{N}$ & $\%$ & $\mathbf{N}$ & $\%$ & $\mathbf{N}$ & $\%$ & $\mathbf{N}$ & $\%$ \\
\hline Penicillin & $11 / 14$ & 78.5 & $14 / 16$ & 87.5 & $39 / 42$ & 92.8 & $28 / 30$ & 93.3 & $23 / 24$ & 95.8 & $115 / 126$ & 91.2 \\
\hline Clindamycin & $11 / 14$ & 78.5 & $13 / 16$ & 81.2 & $39 / 42$ & 92.8 & $27 / 30$ & 90 & $20 / 24$ & 83.3 & $110 / 126$ & 87.3 \\
\hline Ciprofloxacin & $9 / 14$ & 64.2 & $12 / 16$ & 75 & $35 / 42$ & 83.3 & $26 / 30$ & 86.6 & $20 / 24$ & 83.3 & $100 / 126$ & 79.3 \\
\hline Rifampicin & $9 / 14$ & 64.2 & $10 / 16$ & 62.5 & $23 / 42$ & 54.7 & $18 / 30$ & 60 & $11 / 24$ & 45.8 & $71 / 126$ & 56.3 \\
\hline Gentamicin & $6 / 14$ & 42.8 & $6 / 16$ & 37.5 & $19 / 42$ & 45.2 & $14 / 30$ & 46.6 & $12 / 24$ & 50 & $50 / 126$ & 39.6 \\
\hline Tetracycline & $4 / 14$ & 28.5 & $6 / 16$ & 37.5 & $19 / 42$ & 45.2 & $14 / 30$ & 46.6 & $11 / 24$ & 45.8 & $57 / 126$ & 45.2 \\
\hline Linezolid & $0 / 14$ & 0 & $0 / 16$ & 0 & $0 / 42$ & 0 & $0 / 30$ & 0 & $0 / 24$ & 0 & $0 / 126$ & 0 \\
\hline Vancomycin & $0 / 14$ & 0 & $0 / 16$ & 0 & $0 / 42$ & 0 & $0 / 30$ & 0 & $0 / 24$ & 0 & $0 / 126$ & 0 \\
\hline
\end{tabular}


five most prevalent strains (more than 10 isolates) are shown in Figure 1. Among these strains, we found a high biofilm forming rate of $54 \%$.

The resistance rates to penicillin, clindamycin, ciprofloxacin, rifampicin, tetracycline, and gentamicin were $91.2 \%, 87.3 \%, 79.3 \%, 56.3 \%$, $45.2 \%$, and $39.6 \%$, respectively. All 126 strains were susceptible to vancomycin and linezolid (Table 3). According to our results, there is an increasing rate of resistance to clindamycin, ciprofloxacin, rifampicin, gentamicin, tetracycline, and especially penicillin (Figure 2 ).

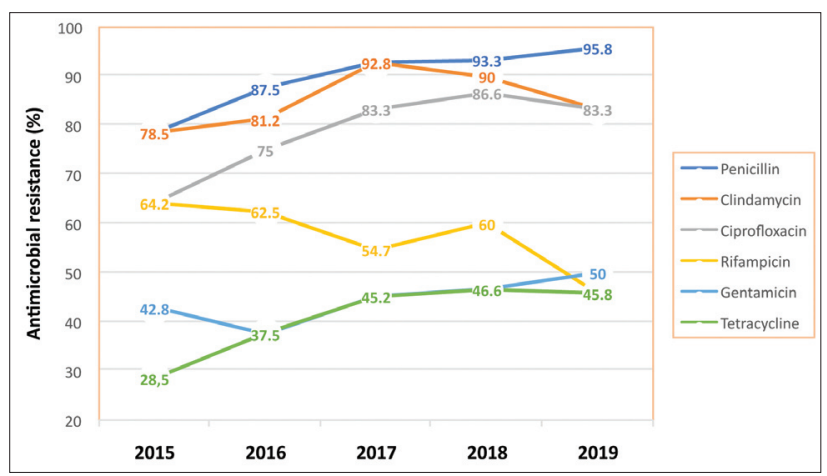

Figure 2. Trends of antimicrobial resistance to penicillin, clindamycin, ciprofloxacin, rifampicin, gentamicin, and tetracycline between 2015-2019.

\section{DISCUSSION}

Corynebacterium spp. are common in the environment and as part of the normal skin flora and mucous membranes. The pathogenic potential of coryneform bacteria has long been underestimated. Long considered as a contaminant, they were ignored as a cause of infection when isolated from clinical specimens in microbiology laboratories ${ }^{11}$. However, owing to the increasing number of immunocompromised patients, Corynebacterium spp., which are usually found as opportunistic pathogens in patients with immune deficiency, have become clinically relevant. In recent years, various non-diphtheriae Corynebacterium spp. have been increasingly reported to be infectious agents in inpatients and have caused outbreaks in ICUs ${ }^{3,5,10}$. Yoldas et al. ${ }^{12}$ showed that more than $10 \%$ of the microbial growth in clinical cultures were Gram-positive bacteria cultured from ICU patients.

Recent studies have increasingly reported that the following strains are important causes of infection: C. striatum, C. jeikeum, C. amycolatum, C. urealyticum, C. afermentans, C. ulcerans, C. minitissimum, $C$. propinquum, and $C$. pseudodiphtheriticum $^{3}$. Studies investigating various clinical specimens have indicated that between $44 \%$ and $71 \%$ of patients with Corynebacterium bacteremia have true infections ${ }^{13-15}$. When coryneform bacteria are isolated from sterile samples such as blood, it is difficult for microbiologists to identify their clinical significance ${ }^{11}$.

However, the lack of single definition of true infection and contamination hinders accurate conclusions regarding the incidence of true Corynebacterium infections ${ }^{15}$. For diagnosing true infection, some researchers use only one bacteriological criterion based on the presence of two or more positive blood cultures, while many studies have reported that time to positivity can be used to distinguish between contamination and bacteremia ${ }^{13,14,16-18}$. Zhang et al. ${ }^{16}$ reported that the time to positivity was $<36 \mathrm{~h}$ in $98 \%$ of bacteremia caused by Gram-positive bacteria. In the present study, positivity was detected within $24 \mathrm{~h}$ for all bacteremia cases. In other studies, patients' clinical conditions were taken into consideration and intravascular catheters were accepted as risk factors for true Corynebacterium infection $^{15,19,20}$.

In the present study, non-diphtheriae Corynebacterium strains that grew in the blood cultures between 2015-2020 (with at least two positive blood cultures) were included if they were compatible with the patients' clinical features. The most common isolated strain was $C$. striatum (23\%) followed by C. matruchotii (21\%). 
S. Ozdemir et al. Biofilm Formation and Antimicrobial Susceptibility of Non-Diphtheriae Corynebacterium Strains Isolated from Blood Cultures: First Report from Turkey

C. striatum strains are rarely isolated from the blood, however they have often been reported as a cause of catheter-associated bloodstream infections and endocarditis ${ }^{3,4,21,22}$. In the present study, we saw that our strains were isolated mainly from samples sent from internal medicine and ICUs.

Although opportunistic infections caused by these microorganisms are mostly endogenous, epidemiological studies have revealed that bacterial transition from patient to patient is possible in ICUs. Hospital staffs play an important role as carriers with their contaminated hands in this transition, according to some studies ${ }^{11,21}$.

A retrospective study conducted by Yanai et al. ${ }^{14}$ demonstrated that $C$. striatum was the most common strain detected in bacteremia patients and infections of more than $50 \%$ of bacteremic patients were catheter-associated. This route of infection has been reported in many studies ${ }^{18,23,24}$.

Forty-four (35\%) strains were isolated from inpatients who used catheters or other foreign bodies in ICUs. Traditionally, skin commensal bacteria have relatively low virulence. However, biofilm-forming ability can be a high-virulence factor for multidrug-resistant $C$. striatum. Previous studies reported that $C$. striatumcauses nosocomial outbreaks associated with biofilm formation ${ }^{4,8}$.

During a nosocomial outbreak in a hospital in Rio de Janeiro, Brazil, the ability of various clones of multidrug-resistant and multidrug-sensitive $C$. striatum strains to form biofilm on the surfaces of foreign materials was investigated. The $C$. striatum type I-multidrug-resistant strain was shown to have the greatest ability to adhere to biotic and abiotic surfaces. This clarified the relationship between biofilm-forming ability, antimicrobial multi-resistance, and clonality ${ }^{6,10}$. All isolates were multidrug-resistant. Since biofilm-forming isolates are limited, we could not assess it statistically.
Biofilm production in non-diphtheriae Corynebacterium strains isolated in blood cultures was first reported by Qin et al. ${ }^{19}$. To the best of our knowledge, this is the first report on biofilmforming non-diphtheriae Corynebacterium in blood culture isolates in Turkey. In our study, 51\% of the strains were biofilm producers. Biofilmforming ability was above average for $C$. striatum strains at a rate of $62 \%$. Similarly, Qin et al. ${ }^{19}$ reported a biofilm production rate of $64.3 \%$ in $C$. striatum strains isolated from blood cultures in Japan.

Previously, non-diphtheriae Corynebacteriumstrains were susceptible to many antibiotics, but recent studies have reported they are multidrug-resistant. Given the increasing use of broad-spectrum antibiotics, multidrug resistance also occurs in nondiphtheriae Corynebacterium strains ${ }^{4,18,25}$. Some studies have shown that antimicrobial resistance rates in biofilm-forming isolates were higher than in non-biofilm producers ${ }^{26}$.

The present study assessed antimicrobial resistance rates over five years, which showed that strains have become more resistant to penicillin, clindamycin, ciprofloxacin, rifampicin, and tetracycline. We found the highest resistance to penicillin in $91.2 \%$, followed by clindamycin in $87.3 \%$ of our isolates Asgin et al. ${ }^{25}$ also reported a resistance rate of $87.7 \%$ to clindamycin in $81 \mathrm{C}$. striatum strains in Turkey. All isolated strains were susceptible to vancomycin and linezolid. So far, no vancomycin or linezolid resistance has been reported.

The resistance rates are in line with some recent studies ${ }^{11,20}$. Especially high penicillin resistance rates were detected in many studies ${ }^{4,16,19}$. In both present and previous reports, vancomycin has been proposed as an empirical therapy for severe infections caused by non-diphtheriaeCorynebacterium species ${ }^{3,11}$. However, the management of antimicrobial treatment for these infections is still fraught with controversies. In 
vitro susceptibility tests have shown that linezolid and tigecycline are effective against coryneform bacteria $^{3}$.

Many studies have recommended vancomycin as the first treatment option when invasive $C$. striatum infection was suspected, because none of the Corynebacterium strains have been reported to have in vitro resistance to vancomycin. If the patient was allergic to vancomycin, linezolid or daptomycin has been recommended ${ }^{4,11,20,27}$. Successful treatment in these cases depends on long-term, high-dose antimicrobial therapy and the removal of foreign body material ${ }^{8}$. These results suggest that non-diphtheriae Corynebacterium strains from inpatients with bacteremia are multidrug-resistant and increasingly have the ability to form biofilms.

\section{CONCLUSION}

Non-diphtheriae Corynebacterium spp. should not be overlooked when isolated from blood cultures, as it may actually be the cause of infection, especially considering their virulent biofilm-forming abilities.

To implement advanced control strategies to reduce non-diphtheriae Corynebacteriumassociated infections in hospitals, it is important to perform effective infection control measures focused on non-diphtheriae-Corynebacterium colonization. It is especially important that healthcare workers comply with hand hygiene and cleaning medical equipment and hospital surfaces with appropriate disinfectants.

Surveillance studies on non-diphtheriae Corynebacterium should also be performed in hospitals to increase awareness of $C$. striatum and other non-diphtheriae Corynebacterium that cause bloodstream infections and to prevent biofilmrelated infections. The results of this study are based on a small sample, so further studies need to be done with greater number of patients.

\section{REFERENCES}

1. Bennett JE, Dolin R, Blaser MJ. (Eds). Mandell, Douglas, and Bennett's principles and practice of infectious diseases. 8th ed. Philadelphia: Elsevier Inc; 2015.

2. Bernard K. The Genus corynebacterium and other medically relevant coryneform-like bacteria. J Clin Microbiol. 2012;50:3152-58. [CrossRef]

3. Daisuke U, Oishi T, Yamane K, Terada K. Corynebacterium striatum bacteremia associated with a catheterrelated blood stream infection. Case Rep Infect Dis. 2017;2017:2682149. [CrossRef]

4. Yoon S, Ha SM, Kwon S, et al. Introducing EzBioCloud: a taxonomically united database of $16 \mathrm{~S}$ rRNA and whole genome assemblies. Int J Syst Evol Microbiol. 2017;67:1613-7. [CrossRef]

5. Severo CB, Guazzelli LS, Barra MB, Hochhegger B, Severo LC. Multiple pulmonary nodules caused by Corynebacterium striatum in an immunocompetent patient. Rev Inst Med Trop Sao Paulo. 2014;52:89-91. [CrossRef]

6. De Souza C, Faria YV, Sant'Anna LO, et al. Biofilm production by multiresistant Corynebacterium striatum associated with nosocomial outbreak. Mem Inst Oswaldo Cruz. 2015;110:242-8. [CrossRef]

7. Jamal M, Ahmad W, Andleeb S, et al. Bacterial biofilm and associated infections. J Chin Med Assoc. 2017;81:711. [CrossRef]

8. Souza MC, dos Santos LS, Sousa LP, et al. Biofilm formation and fibrinogen and fibronectin binding activities by Corynebacterium pseudodiphtheriticum invasive strains. Antonie Van Leeuwenhoek. 2015;107:1387-99. [CrossRef]

9. EUCAST, The European Committee on Antimicrobial Susceptibility Testing. Breakpoint tables for interpretation of MICs and zone diameter. 2019: Version 7.01.

10. Ramos JN, Souza C, Faria YV, et al. Bloodstream and catheter-related infections due to different clones of multidrug-resistant and biofilm producer Corynebacterium striatum. BMC Infect Dis. 2019;19:672. [CrossRef]

11. Kimura SI, Gomyo A, Hayakawa J, et al. Clinical characteristics and predictive factors for mortality in coryneform bacteria bloodstream infection in hematological patients. J Infect Chemother. 2017;23:14853. [CrossRef]

12. Yoldas H, Karagoz I. Association between hemogramderived indices and culture-positive infections in intensive care population. Bratisl Med J. 2019;120:856-9. [CrossRef]

13. Ishiwada N, Watanabe $M$, Murata $S$, Takeuchi N, Taniguchi T, Igari H. Clinical and bacteriological analyses of bacteremia due to Corynebacterium striatum. J Infect Chemother. 2016;22:790-3. [CrossRef]

14. Yanai M, Ogasawasa M, Hayashi Y, Suzuki K, Takahashi $\mathrm{H}$, Satomura A. Retrospective evaluation of the clinical characteristics associated with Corynebacterium species bacteremia. Braz J Infect Dis. 2018;22:24-9. [CrossRef]

15. Rasmussen $M$, Mohlin AW, Nilson B. From contamination to infective endocarditis-a population-based retrospective study of Corynebacterium isolated from blood cultures. Eur J Clin Microbiol Infect Dis. 2020;39:113-9. [CrossRef]

16. Zhang Q, Li D, Bai C, Zhang W, Zheng S, Zhang P, Zhang S. Clinical prognostic factors for time to positivity in 
S. Ozdemir et al. Biofilm Formation and Antimicrobial Susceptibility of Non-Diphtheriae Corynebacterium Strains Isolated from Blood Cultures: First Report from Turkey

cancer patients with bloodstream infections. Infection. 2016;44:583-8. [CrossRef]

17. Leal SM, Jones M, Gilligan PH. Clinical significance of commensal Gram-positive rods routinely isolated from patient samples. J Clin Microbiol. 2016;54:2928-36. [CrossRef]

18. McMullen AR, Anderson N, Wallace MA, Shupe A, Burnham CA. When good bugs go bad: epidemiology and antimicrobial resistance profiles of Corynebacterium striatum, an emerging multidrug-resistant, opportunistic pathogen. Antimicrob Agents Chemother. 2017;61:e01111-17. [CrossRef]

19. Qin L, Sakai Y, Bao R, et al. Characteristics of multidrugresistant Corynebacterium spp. isolated from blood cultures from hospitalized patients in Japan. Jpn J Infect Dis. 2017;70:152-7. [CrossRef]

20. Alibi S, Ferjani A, Gaillot O, Marzouk M, Courcol $\mathrm{R}$, Boukadida J. Identification of clinically relevant Corynebacterium strains by Api Coryne, MALDI-TOFmass spectrometry and molecular approaches. Pathol Biol (Paris). 2015;63:153-7. [CrossRef]

21. Oliva A, Belvisi V, lannetta $M$, et al. Pacemaker lead endocarditis due to multidrug-resistant Corynebacterium striatum detected with sonication of the device. J Clin Microbiol. 2010;48:4669-71. [CrossRef]
22. Chen FL, Hsueh PR, Teng SO, Ou TY, Lee WS. Corynebacterium striatum bacteremia associated with central venous catheter infection. J Microbiol Immunol Infect. 2012;45:255-8. [CrossRef]

23. Yang HS, Kim YJ, Cho SY, Shin E, Lee HJ. Central venous catheter-related bloodstream infection by Corynebacterium striatum identified by $16 \mathrm{~S}$ rRNA and rpoB gene sequencing. Ann Lab Med. 2015;35:548-50. [CrossRef]

24. Yoo G, Kim J, Uh Y, Lee HG, Hwang GY, Yoon KJ. MultidrugResistant Corynebacterium striatum Bacteremia: First Case in Korea. Ann Lab Med. 2015;35:472-3. [CrossRef]

25. Asgin N, Otlu B. Antimicrobial resistance and molecular epidemiology of corynebacterium striatum isolated in a tertiary hospital in Turkey. Pathogens. 2020;9:136. [CrossRef]

26. Aydoğan O, Halipçi Topsakal HN, Ozdemir S, Köksal Çakırlar F. Association between antibiotic resistance and biofilm formation of escherichia coli strains isolated from blood culture. Experimed. 2019;9:60-4. [CrossRef]

27. Werth BJ, Hahn WO, Butler-Wu SM, Rakita RM. Emergence of high-level daptomycin resistance in Corynebacterium striatum in two patients with left ventricular assist device infections. Microb Drug Resist. 2016;22:233-7. [CrossRef] 